\title{
How Australian Aborigines Shaped and Maintained Fire Regimes and the Biota
}

\author{
Vic Jurskis ${ }^{1}$, Roger Underwood ${ }^{2}$, Neil Burrows ${ }^{3,}$ * \\ ${ }^{1}$ Independent Scholar, Eden, Australia \\ ${ }^{2}$ Independent Scholar, Palmyra, Australia \\ ${ }^{3}$ Independent Scholar, Rossmoyne, Australia
}

Email address:

vic.jurskis@gmail.com (V. Jurskis),yorkgum@westnet.com.au (R. Underwood), bigurda1@bigpond.net.au (N. Burrows)

${ }^{*}$ Corresponding author

\section{To cite this article:}

Vic Jurskis, Roger Underwood, Neil Burrows. How Australian Aborigines Shaped and Maintained Fire Regimes and the Biota. Ecology and Evolutionary Biology. Vol. 5, No. 4, 2020, pp. 164-172. doi: 10.11648/j.eeb.20200504.17

Received: October 22, 2020; Accepted: November 12, 2020; Published: November 23, 2020

\begin{abstract}
People proliferated across Australia, which was then a part of Sahul, from about 40000 years ago when megafauna finally disappeared long before the Last Glacial Maximum. The so called 'blitzkrieg' hypothesis proposes that megafauna were extinguished by Aboriginal hunting. It is argued, either that there were some changes in vegetation and fire regimes as a consequence, or that fire regimes and vegetation were largely unaffected by human arrival. However, there is an alternative view that Aboriginal burning changed the vegetation so that megafauna had insufficient food resources to sustain them. We aimed to resolve this debate by examining the published palaeological and historical evidence. This evidence indicates that Aboriginal burning initially turned much biomass into charcoal, reducing browse, changing vegetation and causing megafaunal extinctions. It created ecosystems whose health and safety depend on constant human input of mild fire. Mild burning of these anthropogenic landscapes consumes relatively little biomass and produces relatively little charcoal. Although burning by people has typically been regarded as an ecological disturbance, the historical evidence, together with traditional Aboriginal knowledge, suggests that it is actually maintenance, essential to sustain our natural environment. We conclude that people can reinstate resilient, healthy and safe landscapes irrespective of climate change.
\end{abstract}

Keywords: Aborigines, Australia, Climate Change, Fire Regimes, Megafauna

\section{Introduction}

A view persists that Aborigines had negligible impacts on Australian fire regimes or biota [1], that lightning was more important [2] and that megafauna were gradually eliminated by climate change before and/or after human arrival [3, 4]. This is at odds with traditional Aboriginal knowledge [5] and comprehensive documentation by European explorers, pioneers and scientists, of the ways in which Aboriginal burning maintained the landscape [6-10]. The large influence of Aboriginal burning is evidenced by profound changes in the environment, including loss of plants and intermediate sized mammals after it was disrupted [9-14]. However, the means by which people and/or changing climate contributed to changes in prehistoric landscapes remains contentious [3, 13, 15-19].

It has been argued that the majority of megafauna disappeared from the fossil record in Sahul (a single land mass comprising Australia, New Guinea, Tasmania and many lesser islands) before humans arrived, and that a few coexisted with people for an extended period [3]. However, although reliable extinction dates are not available for most taxa [18], at least 22 survived the extremes of the Penultimate Glacial Maximum and disappeared after humans proliferated [3]. Increased burning of biomass, changes in vegetation, and final extinction of the megafauna occurred during a period of relatively stable climate between about 50000 and 40000 years ago, well before the Last Glacial Maximum (LGM) [16, 18-23].

Debate about global extinctions of megafauna and pre-human extinctions seems to have complicated discussion about the cause of extinctions since human arrival in Sahul [18]. Many palaeologists [16, 18, 19, 24, 25] consider that human impacts primarily drove these megafaunal extinctions. Some consider that single factor explanations are too 
simplistic, but that climate change may have been the main factor [3] or a contributor in some situations [16]. Others argue that climatic/hydrological changes caused the extinction of a giant bird Genyornis newtoni around Lake Eyre [27] and a diverse megafauna in northeastern Australia [4].

There is no physical evidence of humans hunting, killing or butchering megafauna in Australia. Proponents of 'blitzkrieg' rely upon purported lack of evidence of extreme climatic change or significant changes in fire regimes and vegetation coincident with human proliferation, together with evidence of extinctions by human hunting elsewhere [17, 18, 19, 24, 25, 28].

For example, a recent review of the evidence from charcoal in sediment cores reported that "fire in Australasia predominantly reflects climate, with colder periods characterized by less and warmer intervals by more biomass burning ... There is no distinct change in fire regimes corresponding to the arrival of humans in Australia at 50 +/$10 \mathrm{ka}$ " [23]. Consequently it has been suggested that people had little direct impact on fire regimes, but fire increased in some areas because fuel accumulated in the absence of browsing after Aborigines hunted the megafauna to extinction $[17,18,28]$.

A central tenet of the 'blitzkrieg' hypothesis is that megafauna were exterminated within a short time after human arrival in any locality because they were naïve to human predators and therefore easy prey [24]. In respect of Australian megafauna, it further relies heavily on observations that changes in fire regimes and vegetation lagged megafaunal extinctions on the Atherton Tablelands by a century or so [17, $18,24,28]$ and reportedly did not coincide with megafaunal extinctions at Cape Pasley [19]. However, megafauna coexisted with people for millennia whilst dung fungi declined and charcoal firstly increased, then declined in both northeastern and southwestern Australia [16, 19, 28].

Resolution of the debate hinges on two main questions. Firstly, whether there was a general increase in biomass burning and change in vegetation around the time of human proliferation, and secondly, if there was a general change, whether it was caused by Aboriginal burning or by reduced browsing as a consequence of Aboriginal hunting.

\section{The Evidence}

The earliest evidence of human occupation of any site in Australia, currently dates to about 65000 years ago [29]. Sediment cores typically show peaks in charcoal and changes in vegetation, which cannot be explained by climate change, around 40000 years ago - the time that widespread evidence of human occupation begins to appear in archaeological records [16, 20-23]. Recently, authors of a synthesis of charcoal studies reported that there was no obvious change in fire regimes coincident with human proliferation across Australia "at $50+/-10 \mathrm{ka}$ " but that charcoal increased and decreased respectively with cyclic global warming and cooling as evident in ice cores from Greenland [23]. A review of Aborigines' role in megafaunal extinctions built on this synthesis and concluded that megafauna were probably extirpated primarily by hunting, because human arrival had little direct effect on fire regimes or vegetation [18].

However, during the last 70000 years, there was an unusually high amount of charcoal deposited in sediments around 40000 years ago, suggestive of massive burning. A meta-analysis by Mooney et al. shows that the highest rate of deposition occurred across Sahul around 41000 years ago on a geological time scale (2000 year smoothing window) or around 38000 years ago on a millennial time scale (400 year smoothing window) [23]. A trend of increasing charcoal deposition between about 50000 years ago and 40000 years ago does not correspond with any trend in temperature indices from the Greenland ice cores and runs counter to the trend of decreasing temperature indices from Antarctica [18, 23]. Aside from this, the general trend was for increasing charcoal deposition with cooling and drying climate from 70000 years ago to about 32000 years ago, followed by a steep decline as ice sheets developed in the lead up to the Last Glacial Maximum [23].

From the LGM about 20000 years ago, there began a relatively steady increase in temperatures and charcoal deposition [23]. Rising sea levels eventually separated mainland Australia from New Guinea and Tasmania about 10 000-8000 years ago. However, there was an exceptional spike in biomass burning evident in charcoal deposition after European occupation of Australia, followed by a pronounced decline from the mid Twentieth Century coincident with widespread use of prescribed burning [23].

Palaeoclimatic and palynological data from Tasmania and New Zealand show that vegetation changed differently in Tasmania during the last glaciation than it had during three prior glaciations, and during all four glacial cycles in New Zealand. Twice as much open vegetation developed under the influence of Aboriginal burning as would be expected based on climate alone [30]. A comparison of soil development under the influence of Aboriginal burning against soil development in New Zealand where people had not yet arrived, showed that the firestick created relatively infertile, poorly drained soils which supported a distinctive, hard-leaved pyrophilic woody flora [31].

Thus, modern science concurs with the observations and deductions of European explorers. For example, Mitchell wrote that:

Fire is necessary to burn the grass, and form those open forests, ... the native applies that fire to the grass at certain seasons, ... But for this simple process, the Australian woods had probably contained as thick a jungle as those of New Zealand or America [11].

Oxley [32] had described 'jungle', i.e rainforest, in northern NSW -

stately trees, but of what kind we were ignorant: creepers and small timber trees, all of species not previously noticed by us, grew so extremely thick that we found it impossible to penetrate through them ... our progress much impeded by the vast trunks of fallen trees in a state of decay, some of which were upwards of one hundred and fifty feet long, without a branch, as straight as an arrow, and from three to eight and 


\section{ten feet in diameter.}

He called it a "truly primeval forest".

In what is now North Queensland, greatly increased fire activity relative to climate converted araucarian dry rainforest on the Atherton Tableland to grassy sclerophyll woodland between about 40000 and 27000 years ago, by which time charcoal deposition had declined to a relatively low level despite the dry climate. From the LGM about 20000 years ago eucalypt forest began to recolonize the Tableland as climate gradually became warmer and wetter, and charcoal increased $[20,22]$.

By about 9000 years ago it became too wet for people to burn and rainforest reinvasion commenced. Relatively steady influx of charcoal gave way to large peaks and troughs indicative of infrequent ( $\sim 230$ year intervals) high-intensity lightning fires. These fires maintained a mixed forest of eucalypt over rainforest until about 7000 years ago when rainfall had increased to higher than current levels ( $2300 \mathrm{~mm}$ per annum) and there had been no fire for a few centuries. Then the last old eucalypts died out and rainforest gained supremacy. Charcoal declined to very low levels [13, 20, 22, 33].

By contrast, Tasmanian Aborigines were able to maintain savannahs, despite high ( $>2000 \mathrm{~mm})$ winter-dominated rainfall, on elevated plains with relatively poorly developed soils at Surrey Hills. Two temperate rainforest species have proliferated in this area since Europeans disrupted and displaced Aboriginal society [14].

On the Atherton tableland, from about 43000 years ago, fungal spores, presumed to be from megafaunal dung, had decreased in proportion as charcoal increased over about 3000 years [28]. It has been stated that "the major increase of charcoal lagged Sporormiella decline by 100 years" and that changes in vegetation lagged further [28]. At Cape Pasley in southwestern Australia, there was a spike in charcoal deposition about 45000 years ago coincident with a sharp decrease in Sporormiella and a reduction of "woody herbaceous scrub taxa" during the ensuing 2000 years [19]. However, van der Kaars et al. wrote that there was "no sustained change in charcoal flux" at the time [19].

On this evidence it has been argued that hunting by Aborigines rather than climate change or Aboriginal burning extirpated the megafauna $[17-19,28]$. The changes in vegetation and fire regimes on the Atherton Tableland at that time were supposedly a consequence of megafaunal extinctions [17, 28, 30].

Megafaunal extinctions in southwestern Australia coincided with human arrival and there was increased fire activity relative to climate [16]. Studies using the carbon isotopic composition of fossil eggshells and teeth indicate that emus (Dromaius novaehollandiae Latham) and wombats (Vombatus ursinus Burnett) adapted to a poorer diet after Aboriginal burning eliminated mesic vegetation, whereas another large bird, Genyornis, was unable to adapt [34].

A contrary suggestion that Genyornis succumbed to catastrophic drying in Lake Eyre Basin is unconvincing because it previously endured more pronounced drying at Lake Eyre where the shoreline fell $15 \mathrm{~m}$ in elevation to $-4 \mathrm{~m}$ asl before human arrival, whereas the shoreline was $+3 \mathrm{~m}$ asl when the bird disappeared after human arrival [27]. Also, it was simultaneously extirpated at distant sites with different climate and hydrology [34, 35].

There is no evidence of Aborigines hunting megafauna, even though there is evidence of megacarnivores preying on megaherbivores where they coexisted with Aborigines [16]. Eggshells apparently scorched in campfires suggest that Aborigines ate eggs of the extinct Genyornis as well as the extant emu [35]. By contrast, in New Zealand, where Maori hunted another giant bird to extinction, there are hundreds of known butchering/cooking sites containing the remains of up to tens of thousands of moa [24].

After Kangaroo Island was separated from the mainland by rising seas, the last known date of Aboriginal occupation was about 4000 years ago. There was a spike in charcoal and an abrupt change in vegetation around this time, which was attributed to marginally drying climate. A large, sustained increase in charcoal from 2500 years ago indicated infrequent high intensity fires with considerable accumulation of fuel between them. This was attributed to cessation of Aboriginal burning [20]. An alternative scenario is that high intensity fires initiated vegetation change after the demise of Aborigines about 4000 years ago, and dense eucalypt forest developed during the succeeding millennium [13]. In any case, Flinders saw dense forest and clear evidence of infrequent high-intensity lightning fires on this uninhabited island in 1802 [36].

European explorers and naturalists found evidence of recent vegetation change where Aboriginal populations had been reduced or eliminated by diseases [13]. For example, G. A. Robinson wrote that many districts of northeastern Tasmania had been taken over by dense underwood after the demise of local Aborigines [37]. Recent pollen, charcoal and dendrochronological analyses confirmed historical evidence of similar changes after Europeans displaced Aborigines in the northwest of the State [14].

Strzelecki battled through 80 kilometres of almost impenetrable scrub in South Gippsland, where Aborigines had been eliminated by smallpox and tribal warfare before European settlement [37-39]. When settlers cleared the scrub, they found stone axes and spearheads, grindstones, and clay cooking ovens indicating that it had grown up after the demise of the first people [12, 40-42]. The size of the largest young eucalypts in the scrub indicated that it dated from a megafire about 30 years after the smallpox epidemic of 1789 [40].

Curr described some small scrubs that had grown up on Murray River floodplains after Aboriginal people were scourged by smallpox, and he independently deduced the time of the epidemic from the size of trees growing in abandoned cooking ovens [43]. Extensive dense scrubs observed by Mitchell in central Queensland [11] apparently grew up after Aborigines were reduced by smallpox, because their distribution and extent cannot be explained by environmental factors $[13,44]$.

Traditional Aboriginal knowledge and modern ecological science indicate that current widespread eucalypt decline, 
shrub invasion, pestilence and megafires are consequences of lack of frequent mild burning [13, 45-50]. Victor Steffensen, an Aboriginal scion of the Tagalaka people from North Queensland, summarises the problem as "upside-down country - thin on top and thick underneath", and the solution as "fire trickling across the landscape like water, and producing white medicine smoke" (Victor Steffensen pers. comm. 2016).

The charcoal records suggest that people initially used high intensity fires consuming much biomass to shape the ecosystems of Sahul. Aborigines subsequently managed their country with mild fire for tens of thousands of years. However, the most recent reviews of megafaunal extinctions around the time that people spread across most of the continent concluded that there is no evidence to support Aboriginal burning as a cause $[4,18,19]$. Johnson gave the following reasons [18]:

Firstly, because megafauna were widespread, the cause of their demise must also have been widespread as hunting would have been, whilst changes in fire regimes were too weak and geographically variable.

Secondly, a giant kangaroo that ate chenopods became extinct, but fire was not a significant factor in chenopod shrublands because these shrubs had low flammability and wide spacing. Some sediment cores show increasing chenopods with declining charcoal. Habitat destruction by Aboriginal burning can not explain the extinction of giant kangaroos that browsed chenopods.

Thirdly, fire is likely to have improved habitats for large herbivores: "speculation" that burning reduced browse for megafauna "seems implausible" because large feral browsers such as deer have recently proliferated [18].

Johnson used evidence of distinct changes in fire regimes coincident with human arrival at four widely separated sites, together with lack of evidence of changes in fire regimes around the same time at four other widely separated, but geographically overlapping sites, to argue that Aboriginal burning was not widespread [18]. Abrupt changes in fire regimes at half the sites were supposed to be a consequence of megafaunal extinctions by Aboriginal hunting, though there was no evidence of hunting, even of birds' eggs, at any of the sites $[18,35]$. Sediments from one of these sites, in what was an alpine environment at Caledonia Fen [53], indicate that there were no changes in vegetation or fire regime when dung fungi abruptly disappeared around the time of human proliferation in Australia [18].

\section{Discussion}

\subsection{Vegetation, Fire and Charcoal}

Frequent mild burning of open grassy vegetation produces relatively little charcoal and few fire scars because most seedlings are killed and relatively little woody material accumulates. Fire intensity and residence time are relatively low in light fuels composed of litter and grasses, so that heavy fuels, such as large fallen timber and standing green trees are not readily ignited or consumed $[54,55]$. Peaks in charcoal deposition may indicate that large quantities of biomass have been burnt [23], but they do not indicate the frequency of fire in the landscape. Charcoal from individual sediment cores must be thoroughly examined at a very fine (decadal) time scale to enable any assessments of fire frequency and intensity at a particular site [33].

Extinction of a recently discovered diversity of megafauna in northeastern Australia was assessed against climatic, hydrological, vegetation and fire regime changes in a broad region sampled by a marine sediment core known as ODP 820. Hocknull et al. reported climate driven reductions in rainforest and grasslands and increase in charcoal from around 45000 years ago coincident with the disappearance of megafauna after about 40000 years ago [4]. Clearly, ODP820 sampled a mixture of different processes in different parts of the region because grass cannot grow in rainforest, but can increase as rainforest declines.

Hocknull et al. suggested that that the herbivorous megafauna were impacted by a loss of pasture as climate deteriorated, then fire increased as grass increased under reduced grazing pressure [4]. However, they also reported similarities with the local record from Lynch's Crater. Despite the mixed signals combined in the broad regional record, this local record is not entirely obscured. ODP820 does not support the proposition by Hocknull et al. [4] because, despite the drying climate about 27000 years ago, charcoal declined whilst grass increased, as it did after rainforest disappeared at Lynchs Crater [4, 20].

Charcoal concentration from sediment cores synthesized across regions may provide a coarse surrogate for the prevalence of high intensity fires burning dense woody vegetation. Spikes in charcoal concentration within numerous sediment cores around 40000 years ago suggest a widespread increase in burning of woody biomass around the time that widespread evidence of human occupation appears in Australia [4, 16, 19-23]. It is likely that the Aborigines initially occupied grassy areas and extended them by gradually pushing intense fires into thick woody vegetation. After open grassy landscapes were established, mild fires produced less charcoal [13].

A synthesis of records from Sahul over the past 70000 years shows a distinct peak in charcoal around 40000 years ago [23]. This is apparent in records dated at about 43000 years from the Atherton Tableland in northeastern Australia [4, 22, 28, 33], and records dated at about 45000 years from Cape Pasley in southwestern Australia [19]. However, Mooney et al. [23] and Van der Kaars et al. [19] respectively reported that there was no "distinct" or "sustained" change at that time. There seems to be an implication that sustained burning would have continued to produce large quantities of charcoal.

But there is a need to distinguish the kind of fire that could have changed primeval vegetation from the mild burning that maintained anthropogenic landscapes for tens of thousands of years afterwards. Historically, this distinction has been neglected. For example: "Tindale (1959) was the first to state clearly that the Aborigines probably had a profound effect on the vegetation, chiefly by their destructive and uncontrolled 
use of fire for hunting, and that this may have led to animal extinctions. The extensive burning of the countryside by Aborigines in all parts of Australia is attested by numerous observations in historical times" [56].

The charcoal evidence suggests that burning by people, when they first proliferated in Australia, changed the vegetation so that frequent mild burning subsequently produced less charcoal on a more regular basis [13, 20, 33]. Johnson equated lack of spikes in charcoal concentration around the same time, at four dry and/or cold sites, with lack of increased burning by people [18]. However, these sites were not dominated by woody vegetation, and were therefore relatively unproductive of charcoal, whatever the fire regime.

One of these sites showing no change in charcoal or vegetation [25] was in Tasmania, where widespread changes in fire regimes, vegetation and soils after human arrival have been documented [30,31]. Declines in charcoal concentration after spikes at other sites were associated with changes in vegetation such as increases of grasses or chenopods [18, 20, 28] or reductions of woody herbaceous taxa [19].

European explorers and pioneering pastoralists described frequent mild burning of mostly open grassy ecosystems by Aboriginal people [6-8, 10-13, 36, 43, 44, 57, 58]. On the other hand, Mooney et al. compared a rough index of human occupation from archaeological sites in the arid zone against charcoal in sediment cores mostly from the humid zone. They claimed a lack of correlation as evidence that Aborigines did not influence fire regimes [23]. Apart from the geographical separation of the independent and dependent variables, and the paucity of dated Aboriginal sites before about 20000 years ago [23], the analysis is invalid because high rates of charcoal deposition cannot be equated with frequent Aboriginal burning in open grassy ecosystems.

An outstanding spike in biomass burning during 70000 years of records occurred after European settlement. This evidence suggests that woody thickening and intense fires consequent to disruption of Aboriginal burning fueled megafires that produced unprecedented amounts of charcoal $[11,23,52]$. The first known megafire after Europeans in arrived in 1788 occurred around 1820, prior to European occupation of what is now Victoria. It established dense young eucalypt forest in the Strzelecki Ranges [12, 40]. Dendrochronology has dated a megafire in the nearby Central Highlands at 1824 [59].

This first known high intensity fire event in The Strzelecki Ranges was almost certainly a consequence of lack of mild burning after the demise of the Yowenjerre people. The disruption of Aboriginal fire management likely applied to a wider area including the Central Highlands. Within two decades after Europeans began to disrupt Aboriginal fire management across Victoria, high intensity fires burnt 5 million ha in the Black Thursday fires of $1851[13,60]$. Woody thickening, megafires and pestilence occurred firstly when Aboriginal burning was disrupted, and secondly when foresters attempted to suppress fire in the early $20^{\text {th }}$ Century $[13,50]$.
When foresters introduced broad area prescribed burning, including aerial ignition, after the mid- $20^{\text {th }}$ Century, forest health and fire safety improved $[13,46,49,50]$ and there was a pronounced general decline in charcoal deposition [23]. Mooney et al. described this as a robust feature of the record [23] and it runs counter to the trend of rising temperature. Since the late $20^{\text {th }}$ Century, burning has again been reduced, mostly as a result of environmental concerns, and woody thickening, megafires and pestilence have returned with a vengeance $[13,49,50]$.

During the 2019-2020 wildfire season, 8.2 million hectares of native forest were burnt in southeast Australia, much of this at very high intensities. Thirty-three people were killed, 3100 homes were destroyed and losses of native fauna are incalculable [61]. The recent upsurge in charcoal deposition as a result of increasing megafires apparently is yet to be sampled in sediment cores and reported in the literature. However, awareness of the critical role of mild burning in maintaining ecosystem health and safety has been reawakened by traditional Aboriginal and non-Aboriginal land managers [13, $9,50,61,62]$. Unfortunately mild burning has become more difficult as a result of vegetation changes in its absence, and counter-productive regulations and procedures [50]. At the same time, fire knowledge and skills of both Aboriginal people and non-Aboriginal pastoralists and foresters are being lost with our elders $[5,9]$.

\subsection{Impacts of Fire or Hunting on Vegetation and Megafauna}

There are various reasons at various sites, which could explain why changes in charcoal deposition either preceded or lagged palynological evidence of changes in vegetation, or did not occur. For example, there may be different relationships between fire and charcoal production according to vegetation type, different geographical sources of charcoal and pollen, and differences in mode and speed of transport from source to deposit [13, 22, 33].

An analysis of changes over time in fungal spores (presumed to be from megafaunal dung), charcoal and vegetation at Lynchs Crater [28] concluded that fire should be ruled out as a cause of megafaunal extinction, merely because peak rates of change in charcoal concentration, and in pollen composition in sediments, lagged the peak rate of change in Sporormiella concentration by a century or so [17, 18, 28]. However fungal spores decreased as charcoal peaked and vegetation changed over millennia in both northeastern and southwestern Australia [19, 28].

The evidence of changes in dung fungi, charcoal and vegetation suggests to us that megafauna suffered a protracted decline as Aborigines initially reduced accessible browse by scorching or burning leaves of shrubs, and gradually burnt more dead and live wood. Consequently, charcoal deposition temporarily increased, then grasses or chenopods increased as woody vegetation declined, and eventually the composition of the entire flora, including long-lived trees changed [13, 20, 22].

It has been proposed that woody thickening after the elimination of browsing by megafauna caused changes in fire 
regimes $[17,18,28]$. If so, there should be evidence of this in sediment cores. For example, the increases in grasses and sclerophylls at the expense of mesic vegetation at Lynch's Crater must have been preceded by a reduction in grasses at the expense of mesic woody vegetation for this hypothesis to be sustained. There was no evidence of this $[20,28]$, so the hypothesis is untenable. In contrast, there is abundant evidence of reduction in herbs, grasses and sedges as a result of post-European woody thickening [13] including palynological evidence from post-European red gum (Eucalyptus camaldulensis) forests [63].

Johnson argued it is implausible that Aboriginal burning reduced megafaunal browse, given that large browsers such as deer have recently proliferated [18]. On the contrary, it seems clear that mesic woody vegetation initially declined under widespread Aboriginal burning, and later proliferated whenever the frequency of landscape burning was reduced in prehistoric, historic and modern times, for whatever reason [5, $11-14,20,22,64]$. Plagues of feral goats [65] and deer [66] have attended recent woody thickening in semiarid and humid zones respectively [13, 18].

Sites containing accumulations of burnt eggshells of Genyornis also have burnt eggshells of emus which continued to be hunted long after the extinction of Genyornis [35]. This provides strong evidence that Aboriginal arrival coincided with the bird's extinction [18] but no evidence that hunting was the primary cause [35].

Proponents of the 'blitzkrieg' hypothesis seek to explain lack of evidence that Australian Aborigines hunted megafauna, compared to abundant evidence of killing or butchering sites in North America and New Zealand, on the basis that geological disturbances over a much longer time period have destroyed it, so there is a scarcity of sufficiently ancient archaeological sites [17, 18, 24, 35]. Conversely, Mooney et al. used this scarcity of ancient evidence to infer scarcity of human occupation [23].

Nevertheless, there is physical evidence of megacarnivores preying on megaherbivores where they coexisted with Aborigines, and increased burning of woody biomass, unrelated to climate change, in the same area at the same time [16]. Long coexistence with megafauna and no evidence of hunting by Aborigines challenges a central tenet of the blitzkrieg hypothesis [17, 24].

Absence of evidence for hunting or butchering together with evidence of protracted decline of megafauna has prompted the development of a modified overkill hypothesis known as 'imperceptible overkill'. Van der Kaars et al. argued that megafauna were vulnerable, even to low hunting pressure, because of low fecundity. They suggested that people taking only one juvenile animal per decade could exterminate a species within a few centuries and this could explain the lack of evidence of kill sites [19].

However, this modified hypothesis cannot explain absence of evidence of killing/butchering technology from sites containing tools from the relevant period [3]. Also it is most unlikely that people with the skills and technology to hunt big game would employ them so sparingly. Fifteen species of megafauna disappeared from southwestern Australia over several millennia whilst a medium-sized kangaroo and most smaller animals survived [16]. A slow attrition of individual species by very occasional hunting appears to us an unlikely explanation that doesn't seem to fit with any known survival strategies of hunter-gatherers.

An abrupt decline in dung fungi occurred midway through the last glacial cycle, around the time of human influx/proliferation in Australia, in a cool grass-shrub steppe with low-moderate fire activity according to the charcoal record. There were no coincidental changes in fire regimes or vegetation apparent in the sediment cores. This unexplained decline was offered as evidence that Aboriginal burning did not cause megafaunal extinctions [18]. However, it is likely that the alpine site became too cold for megafauna, and that Aborigines did not start to utilise the site until climate ameliorated and trees colonized it in the current interglacial. European explorers noted absence of kangaroos and emus from alpine sites [13].

Johnson's suggestion that fire regimes played no part in the ecology of chenopod shrublands [18] is contradicted by two observations: firstly, that these shrublands increased as charcoal declined after Aborigines had colonized Australia [18]; secondly, that chenopods were replaced by thick swards of grass after Aboriginal burning was disrupted by European pastoralists [43]. He also referred to the lack of a charcoal spike in one sediment core - GC-17 - around the time of human increase, as evidence of lack of burning [18]. Grassy eucalypt woodland in this catchment changed to Eucalyptus and Gyrostemon shrubland containing chenopods between 46, 000 and 40, 000 years ago during a dry period [61]. However, there is an 18, 000 year hiatus in the record before 46,000 years ago [67] so it seems unclear whether Aboriginal burning had any involvement in the vegetation changes.

Increases in chenopods and reductions in charcoal after Aboriginal arrival can perhaps be explained as a consequence of reductions of woody vegetation and robust grass tussocks by frequent mild burning [13, 22, 43] and/or increasing aridity [67]. At the same time, destruction by Aboriginal burning of scattered patches of woody vegetation providing megaherbivores with shelter (from weather and megacarnivores) and/or increasing cold/aridity, may have contributed to the loss of giant chenopod-eating kangaroos. For example, a European explorer noted that kangaroos escaped from dingoes by retreating from their foraging grounds into woody scrubs. Also, Charles Darwin predicted the extinction of kangaroos after their numbers had dramatically declined during severe drought in $1836[13,58]$. There is no evidence to support Johnson's suggestion [18] that giant chenopod-eating kangaroos were exterminated by Aboriginal hunting.

\section{Conclusion}

Aborigines ate big birds' eggs, but there is no evidence that they killed or butchered megafauna. Also, there is no evidence that vegetation changed as a consequence of megafaunal extinctions before biomass burning increased. There was a 
continental increase in burning of woody vegetation around the time of Aboriginal influx/proliferation, together with widespread changes in vegetation. Subsequently, mild fire regimes resulted in reduced biomass burning and charcoal deposition. Later, charcoal deposition declined steeply with increasing aridity and decreasing temperature for 10000 years leading to the LGM.

After the LGM about 20000 years ago, woody vegetation and charcoal deposition gradually increased as climate became warmer and wetter. When the arrival of Europeans or their diseases disrupted Aboriginal burning there was very rapid woody thickening which fueled extensive high intensity firestorms or megafires that produced unprecedented quantities of charcoal.

Aboriginal occupation of the continent was neither instantaneous nor uniform [68]. Nevertheless, widespread Aboriginal burning likely exterminated most of the remaining megaherbivores by eliminating their browse or, possibly in some cases, their shelter. The remaining megacarnivores disappeared with their prey or 'scavenge'. Open grassy ecosystems dependent on human application of mild fire became widely established.

The evidence suggests that burning by people overwhelmed climatic influences on biota and fire regimes, except at the extremes where it became too wet to burn or too cold and/or dry for tall woody vegetation and megafauna. The corollary is that people can reinstate resilient, healthy and safe landscapes irrespective of climate change. Reintroduction of frequent mild burning must be the top priority for management of ancient anthropogenic ecosystems.

\section{References}

[1] Horton, D. R. (1982) The burning question: Aborigines, fire and Australian ecosystems. Mankind 13 (3), 237-251

[2] Egloff, B. (2017) Lightning strikes: rethinking the nexus between Australian indigenous land management and natural forces. Australian Forestry 80, 275-85.

[3] Wroe, S, Field, J. H., Archer, M., Grayson, D. K., Price, G. J., Louys, J., Faith, J. T., Webb, G. E., Davidson, I., Mooney, S. D. (2013) Climate change frames debate over the extinction of megafauna in Sahul (Pleistocene Australia-New Guinea). PNAS 110 (22), 8777-8781. doi: 10.1073/pnas.1302698110.

[4] Hocknull, S. A., Lewis, R., Arnold, L. J., Pietsch, T., Joannes-Boyau, R., Price, G. J., Moss, P., Wood, R. et al. (2020) Extinction of eastern Sahul megafauna coincides with sustained environmental deterioration. Nature $\begin{array}{llll}\text { Communications } & 11: & 2250 & \text { doi. }\end{array}$ org/10.1038/s41467-020-15785-w.

[5] Steffensen, V. (2020) Fire Country. How indigenous fire management could help save Australia. Hardie Grant Travel, Melbourne.

[6] Hallam, S. J. (1975). Fire and hearth: a study of Aboriginal usage and European usurpation in south-west Australia. Australian Institute of Aboriginal Studies, Canberra.

[7] Hallam, S. J. (2002). Peopled landscapes in Southwestern
Australia in the early $1800 \mathrm{~s}$ : Aboriginal burning off in the light of Western Australian historical documents. Journal of the Royal Western Australian Historical Society 2, 177-191.

[8] Gott B. (2005). Aboriginal fire management in south-eastern Australia.: aims and frequency. Journal of Biogeography 32, 1203-1208.

[9] Burrows, N. D., Burbidge, A. A., Fuller, P. J. and G. Behn. (2006) Evidence of altered fire regimes in the Western Desert region of Australia. Conservation Science Western Australia 5, 272-284.

[10] Gammage, B. (2011) The Biggest Estate on Earth: How Aborigines Made Australia. Sydney: Allen \& Unwin.

[11] Mitchell, T. L. (1848). Journal of an expedition into the interior of tropical Australia in search of a route from Sydney to the Gulf of Carpentaria. London: Longman, Brown, Green and Longmans. Facsimile edition 2007. Ridgehaven, South Australia: Archive CD Books Australia.

[12] Howitt, A. W. (1891) The eucalypts of Gippsland. Transactions of the Royal Society of Victoria II, 81-120.

[13] Jurskis, V. (2015) Firestick ecology: fairdinkum science in plain English. Australia: Connor Court.

[14] Fletcher, M. S., Hall, T., Alexandra, A. N. (2020) The loss of an indigenous constructed landscape following British invasion of Australia: An insight into the deep human imprint on the Australian landscape. Ambio https://doi.org/10.1007/s13280-020-01339-3.

[15] Bowman, D. M. J. S. (1998) Tansley review No. 101: The impact of Aboriginal landscape burning on the Australian biota. New Phytologist 140, 385-410.

[16] Prideaux, G. J., G. A. Gully and A. M. C. Couzens, et al. (2010) Timing and dynamics of Late Pleistocene mammal extinctions in southwestern Australia. PNAS 107, 22157-22162.

[17] Flannery, T. F. (2012) After the future: Australia's new extinction crisis. Quarterly Essay 48, 1-80.

[18] Johnson, C. N. (2016) Fire, people and ecosystem change in Pleistocene Australia. Australian Journal of Botany 64, 643-651.

[19] Van der Kaars, S., Miller, G. H., Turney, C. S. M., Cook, E. J., Nurnberg, D., Schonfeld, J., Kershaw, A. P., Lehman, S. J. (2017) Humans rather than climate the primary cause of Pleistocene megafaunal extinction in Australia. Nature Communications. 8: 14142 DOI:

10.1038/ncomms14142|www.nature.com/naturecommunicatio ns.

[20] Singh, G., A. P. Kershaw, and R. Clark. (1981) Quaternary vegetation and fire history in Australia. In A. M. Gill, R. H. Groves, and I. R. Noble (Eds.) Fire and the Australian biota,. Canberra: Australian Academy of Science, pp. 23-54.

[21] Kershaw, A. P., J. S. Clark, A. M. Gill and D. M. D'Costa (2002) A history of fire in Australia. In: R. A. Bradstock, J. E. Williams, A. M. Gill (Eds.) Flammable Australia: the Fire Regimes and Biodiversity of a Continent, Cambridge: Cambridge University Press, pp3-25. 
[22] Kershaw, P., S. Van Der Kaars, P. Moss, et al. (2006) Environmental change and the arrival of people in the Australian Region. Before Farming: The Archaeology and Anthropology of Hunter-Gatherers 2006 (1) Article 2.

[23] Mooney, S. D., S. P. Harrison, P. J. Bartlein, et al. (2011) Late quaternary fire regimes of Australia. Quaternary Science Review 30, 28-46. doi: 10.1016/j.quascirev.2010.10.010.

[24] Flannery, T. F. (1994) The Future Eaters. Sydney: Reed New Holland.

[25] Turney C. S. M., T. F. Flannery, R. G. Roberts, et al. (2008) Late-surviving megafauna in Tasmania, Australia, implicate human involvement in their extinction. PNAS 105 (34), 12150-12153.

[26] Wroe, S. Field, J., Fullagar, R., Jermiin, L. S. (2004) Megafaunal extinction in the Late Quaternary and the global overkill hypothesis. Alcheringa, 28: 1, 291-331, DOI: $10.1080 / 03115510408619286$.

[27] Cohen, T. J., J. D. Jansen and L. A. Gliganic et al. (2015) Hydrological transformation coincided with megafaunal extinction in central Australia. Geology 43 (3), 195-198.

[28] Rule, S., B. W. Brook, S. G. Haberle, C. S. M. Turney, A. P. Kershaw, and C. N. Johnson (2012) The Aftermath of Megafaunal Extinction: Ecosystem transformation in Pleistocene Australia. Science 335, 1483-1486.

[29] Clarkson, C., Z. Jacobs, B. Marwick, R. Fullagar, L. Wallis, M. Smith, R. G. Roberts, E. Hayes, et al. (2017). Human occupation of northern Australia by 65,000 years ago. Nature 547,306 .

[30] Jackson, W. D. (1999) The Tasmanian legacy of man and fire. Papers and Proceedings of the Royal Society of Tasmania 133 (1), 1-14.

[31] McIntosh, P. D., M. D. Laffan, and A. E. Hewitt (2005) The role of fire and nutrient loss in the genesis of the forest soils of Tasmania and southern New Zealand. Forest Ecology and Management 220, 185-215.

[32] Oxley, J. J. W. M. (1820) Journals of Two Expeditions into the Interior of New South Wales Undertaken by Order of the British Government in the years 1817-18. John Murray/University of Sydney Library, London/Sydney, Etext 2002.

[33] Chen, Y. (1986) Early Holocene vegetation dynamics of Lake Barrine Basin Northeast Queensland Australia. Thesis submitted for the degree of Doctor of Philosophy at the Australian National University, October 1986.

[34] Miller, G. H., J. W. Magee, M. Smith, et al. (2016) Human predation contributed to the extinction of the Australian megafaunal bird Genyornis newtoni $\sim 47 \mathrm{ka}$. Nature Communications 7: 10496. doi: 10.1038/ncomms10496.

[35] Miller, G. H., M. L. Fogel, J. W. Magee, M. K. Gagan, S. J. Clarke and B. J. Johnson (2005) Ecosystem collapse in Pleistocene Australia and a human role in megafaunal extinction. Science 309, 287-290.

[36] Flinders, M. (1814) A voyage to Terra Australis; undertaken for the purpose of completing the discovery of that vast country, and prosecuted in the years 1801, 1802, and 1803, in His Majesty's ship the Investigator, and subsequently in the armed vessel Porpoise and Cumberland schooner. With an account of the shipwreck of the Porpoise, arrival of the Cumberland at Mauritius and imprisonment of the commander during six years and a half in that island. Pall-Mall: G. and W. Nicol, Facsimile edition, 1966. Project Gutenberg Australia Ebook. $<$ http://gutenberg.net.au/ebooks/e00049.html\#chapter1-7>. Accessed 16 Jun 2013.

[37] Flood, J. (2006) The Original Australians: story of the Aboriginal people. Crows Nest: Allen \& Unwin.

[38] Strzelecki, P. E. (1845) Physical Description of New South Wales and Van Dieman's Land, accompanied by a Geological Map, Sections and Diagrams, and Figures of the organic remains. Google Books. Available online: https://play.google.com/books/reader?id=ftUKAAAAIAAJ\&p rintsec $=$ frontcover\&output $=$ reader $\&$ hl $=$ en $\& p g=$ GBS.PR 1 (accessed 10 April 2016).

[39] Wesson, S. (2000) An historical atlas of the aborigines of eastern Victoria and far south-eastern New South Wales. Monash publications in geography and environmental science Number 53. Caulfield: Monash Print Services.

[40] Coverdale, T. J. 1920 The scrub. In (Eds.) Committee of the South Gippsland Pioneers Association, The land of the lyrebird. A story of early settlement in the great forest of South Gippsland, Melbourne: Gordon and Gotch, pp 31-47.

[41] Dodd, F. (1920) Recollections and Experiences. In: The Land of the Lyrebird. A Story of Early Settlement in the Great Forest of South Gippsland. South Gippsland Pioneers' Association. Facsimile reproduction. Forgotten Books, London. pp. 140-8.

[42] Holmes, W. H. C. (1920) Scrub Cutting. In: The Land of the Lyrebird. A Story of Early Settlement in the Great Forest of South Gippsland. South Gippsland Pioneers' Association. Facsimile reproduction. Forgotten Books, London. pp. 67-78.

[43] Curr, E. M. (1883) Recollections of squatting in Victoria, then called the Port Phillip District, from 1841 to 1851. Australian facsimile edition, 1968. Adelaide: Libraries Board of South Australia.

[44] Pyne, S. J. (1991) Burning bush. A fire history of Australia. Seattle: University of Washington Press.

[45] Jurskis, V., Turner, J. (2002). Eucalypt dieback in eastern Australia: a simple model. Australian Forestry 65, 81-92.

[46] Jurskis, V., Bridges, B., de Mar, P. (2003) Fire management in Australia: the lessons of 200 years. In Joint Australia and New Zealand Institute of Forestry Conference Proceedings, 27 April-1 May 2003, Queenstown, New Zealand. Eds. E. G. Mason, C. J. Perley. Ministry of Agriculture and Forestry, Wellington, New Zealand, pp. 353-68.

[47] Jurskis, V., Turner, J., Lambert, M., Bi, H. (2011) Fire and N cycling: getting the perspective right. Applied Vegetation Science 14, 433-4. doi: 10.1111/j.1654-109X.2011.01130.x.

[48] Jurskis, V. (2005) Eucalypt decline in Australia, and a general concept of tree decline and dieback. Forest Ecology and Management 215, 1-20.

[49] Jurskis, V. (2011) Human fire maintains a balance of nature. In Proceedings of Bushfire CRC \& AFAC 2011 Conference Science Day, 1 September 2011, Sydney, Australia. Ed. R. P. Thornton Bushfire Cooperative Research Centre, Melbourne, Australia. pp. 129-38. 
[50] Jurskis, V. (2020) The great koala scam: green propaganda, junk science, government waste \& cruelty to animals. Australia: Connor Court.

[51] Turner, J., Lambert, M., Jurskis, V., Bi, H. (2008) Long term accumulation of nitrogen in soils of dry mixed eucalypt forest in the absence of fire. Forest Ecology and Management 256 $1133-42$.

[52] Jurskis, V., Underwood, R. (2013) Human fires and wildfires on Sydney sandstones: History informs fire management. Fire Ecology 9 (3), 8-24.

[53] Kershaw A. P., G. M. Mackenzie, N. Porch, et al. (2007) A high-resolution record of vegetation and climate through the last glacial cycle from Caledonia Fen, southeastern highlands of Australia. Journal of Quaternary Science 22, 481-500. doi: $10.1002 / j q s .1127$.

[54] Burrows, N. D., B. Ward and A. D. Robinson. (1995) Jarrah forest fire history from stem analysis and anthropological evidence. Australian Forestry 58 (1), 7-16. doi: 10.1080/00049158.1995.10674636.

[55] Hollis, J. J., Anderson, W. R, McCaw, W. L, Cruz, M. G., Burrows, N. D, Ward, B., Tolhurst, K. J. and Gould, H. S. (2011) The effect of fireline intensity on woody fuel consumption in southern Australian eucalypt forest fires. Australian Forestry 74, 81-96.

[56] Calaby, J. H. (1971) Man, fauna, and climate in aboriginal Australia. In: Mulvaney, DJ; Golson, J., (Eds.) Man, fauna, and Climate in Aboriginal Australia. ANU Press, Canberra pp. 80-93.

[57] Tench, W. (1793) A complete account of the settlement at Port Jackson including an accurate description of the situation of the colony; of the natives; and of its natural productions. London: G. Nichol and J. Sewel. Available online: $<$ http://adc.library.usyd.edu.au/data-2/p00044.pdf $>$. Accessed 16 Jun 2013.

[58] Darwin, C. (1845) The voyage of the Beagle. http://www.gutenberg.org/cache/epub/944/pg944-images.html
[59] Lindenmayer, D., Blair, D., McBurney, L., Banks, S. (2015) Mountain Ash: fire, logging and the future of Victoria's giant forests. CSIRO Publishing, Clayton South, Australia.

[60] Adams, M., Attiwill, P. (2011) Burning issues. Sustainability and management of Australia's southern forests. Collingwood: CSIRO Publishing.

[61] Davey, S., Sarre, A. (2020) Editorial: the 2019/20 Black Summer bushfires. Australian Forestry, DOI: 10.1080/00049158.2020.1769899.

[62] Russell-Smith, J., G. D. Cook and P. M. Cooke, et al. (2013) Managing fire regimes in north Australian savannas: applying Aboriginal approaches to contemporary global problems. Frontiers in Ecology and Environment 11 (1), e55-e63.

[63] Kenyon, C. and I. D. Rutherfurd (1999) Preliminary evidence for pollen as an indicator of recent floodplain accumulation rates and vegetation changes: The Barmah-Millewa Forest, SE Australia. Environmental Management 24 (3), 359-367.

[64] Stanton, P., D. Stanton, M. Stott, and M. Parsons. (2014) Fire exclusion and the changing landscape of Queensland's Wet Tropics Bioregion. Australian Forestry 77 (1), 51-68.

[65] Pople, T., Froese, J. (2012) Distribution, abundance and harvesting of feral goats in the Australian rangelands 1984-2011. State of Queensland, Department of Employment, Economic Development and Innovation, 2012.

[66] NSW Department of Primary Industries (2019) Feral deer in New South Wales. September 2019, Primefact 1678, Third edition Invasive Species Biosecurity. State of New South Wales.

[67] Van Der Kaars S. and P. De Deckker (2002) A late Quaternary pollen record from deep-sea core Fr10/95 GC17 offshore Cape Range Peninsula, northwestern Western Australia. Review of Palaeobotany and Palynology 120 (1), 17-39. doi: 10.1016/S0034-6667(02)00075-1.

[68] Flood, J. (1983) Archeology of the Dreamtime. Collins Publishers, Sydney, Australia. 